Article

\title{
How Roads Affect the Spatial Use of the Guanaco in a South American Protected Area: Human Connectivity vs Animal Welfare
}

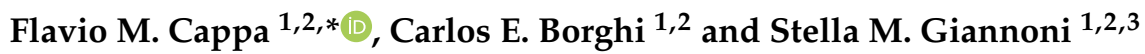 \\ 1 INTERBIODES (Interacciones Biológicas del Desierto), Facultad Ciencias Exactas, Físicas y Naturales, \\ Universidad Nacional de San Juan, San Juan J5400ARL, Argentina \\ 2 CIGEOBIO, UNSJ-CONICET (Centro de Investigaciones de la Geósfera y Biósfera, Universidad Nacional de \\ San Juan-Consejo Nacional de Investigaciones Científicas y Técnicas), San Juan J5400ARL, Argentina \\ 3 Instituto y Museo de Ciencias Naturales, Facultad Ciencias Exactas, Físicas y Naturales, Universidad \\ Nacional de San Juan, San Juan J5400ARL, Argentina \\ * Correspondence: flaviocappa@unsj-cuim.edu.ar; Tel.: +54-264-4260353; Fax: +54-264-4234980
}

Received: 19 March 2019; Accepted: 2 July 2019; Published: 12 July 2019

\begin{abstract}
Roads can affect animals as well as their habits at different levels. Avoidance behavior is a common response of animals to this type of perturbation, preventing access to areas rich in resources. The effects of roads on ungulates have not been studied in South America extensively, especially in arid environments. We have studied the space use by ungulates in relation to roads, using a dung heap count and camera traps. The aim was to evaluate whether paved road and unpaved road may have an effect on the spatial use of a low density population of guanacos (Lama guanicoe) in Ischigualasto Provincial Park, Argentina. We observed an increase in dung heap abundance in unpaved road as respect to paved road, this difference was larger for both. Besides, we recorded less individuals in paved road zones than in unpaved road zones. This showed that roads, especially paved roads, negatively affect the space used by guanacos. Our results are relevant to the management and conservation of animal populations in protected areas since spatial segregation due to the presence of roads may lead to the isolation of individuals. It is important to pay attention and further assess the effects that roads can have in the native fauna.
\end{abstract}

Keywords: avoidance behavior; camera trap; dung heap count; Lama guanicoe; roads

\section{Introduction}

At the moment, one of the major threats posed to biodiversity by human development is infrastructural development since it adversely affects nearby environments [1,2]. The presence of these infrastructures may cause animals to move to less disturbed and less productive areas due to the fact that in animals the trade-off between energy take and disturbances (i.e. human presence or infrastructures) is a key factor in space use variations [2]. This has been observed in different ungulates as mule deer Odocoileus hemionus, wapiti Cervus canadensis, gazelle Gazella gazelle gazella, and guanaco Lama guanicoe which tend to avoid populated areas as well as adjacent areas [3-5].

One of the most common elements of human infrastructures present in almost all habitats are roads [1]. These infrastructures could increase $60 \%$ in their extension by 2050 [6] and they have been placed among the top ten biodiversity threats [7]. Their construction and use generate clearance, compacts substrate, animal mortality by collision with vehicles, but also introduces alien elements to the ecosystems such as chemical elements, noise and exotic species, among others, [1,8,9]. Roads can modify or reduce habitat area and quality, causing animals to avoid these sites. In addition, roads can act as semipermeable barriers and can prevent animals from reaching high quality resource 
patches $[1,10,11]$. This in turn, may produce isolation and contribute to the reduction in gene flow affecting the genetic diversity of the species [12]. Roads have more negative effects on larger animal species, with great mobility [13], low reproduction rates and low density [14]. All of these effects can vary with the distance from roads, being less intense as distances increase. The effects can extend to several kilometers away, depending on the road type, traffic volume and habitat crossed. Besides, it is important to mention that these effects change according to habitat, with arid environments being some of the least studied [15-17].

The effects of roads on ungulates has been studied extensively in North America and Europe, since collisions between vehicles and wild ungulates have generated serious economic problems as well as problems in human and animal welfare $[18,19]$. In order to know how roads affect ungulates and how this problem can be solved, it is essential to study the space use by ungulates in relation to human infrastructures. For example, in some countries in North America and Europe, it has been observed that different ungulates such as the female elk Cervus elaphus, mule deer, wapiti and woodland caribou Rangifer tarandus caribou present some levels of avoidance to roads. However, this is not the case in South America since not much research has been carried out to study the effects of human infrastructure on animals (i.e., guanaco) [20,21].

In South America, guanaco is one of the largest and most widely distributed native ungulate. It is a resource-defense polygynous species, with family groups including one territorial male, females and their offspring [22]. This species has suffered a decrease in its original distribution as a consequence of legal and illegal hunting, competition with livestock, and habitat fragmentation and loss [23]. Thus, extensive research on this species has been carried out, including a wide range of topics such as forensic genetics [24], diet [25,26], behavior [27,28], and management [29].

Due to the current development and increase of awareness in road ecology in Argentina, more research is being carried out on guanaco-road relation. For example, Radovani et al. [30] evaluated how the network of unpaved road (seismic lines) and their use by poachers affected density, recruitment and social structure of guanacos in the North of Patagonia. Moreover, in La Payunia Reserve in the Province of Mendoza, Argentina, Taraborelli et al. [20] found a positive and direct relation between vehicle traffic and group size of guanacos. Cappa et al. [31], in Ischigualasto Provincial Park, San Juan, Argentina (hereafter IPP), found that when guanacos are close to roads, they spend less time in vigilance and more in foraging, giving supporting evidence that these animals perceive these sites as safer. This is in line with the results obtained by Schroeder et al. [21] in La Payunia Reserve which also show that unpaved road has a neutral effect on the spatial use. Although, new information has been obtained about guanaco-roads interaction, it is necessary to continue with the research, especially when it comes to protect a vulnerable population (Secretaría de Estado de Ambiente y Desarrollo Sustentable, Resolución $\mathrm{N}^{\circ}$ 0656) that is exposed to an expanding tourism [32,33].

At the IPP, in a protected area located at the hyper arid extreme of the Monte Desert, there exists a small guanaco population $\left(<0.4 \mathrm{ind} / \mathrm{km}^{2}\right)$ [34] that could be exposed to a high risk of local extinction $(\approx$ 500 ind) [35]. Until recently, only tourists came to this protected area. Nevertheless, since the opening of the road that crosses this protected area, there has been a substantial increase in vehicular traffic and tourist activity [32]. This is because the new paved road, the National route $\mathrm{N}^{\circ} 150$, will be part of the Central Bioceanic Corridor, a paved road that will link ports located in the Pacific (Chile) and Atlantic coasts (Brazil). On the other hand, the PPI, as other protected areas, was primarily designed to conserve their natural resources, without considering visitor access [36]. Thus, a great challenge of this protected area is to combine their conservation with the permanent increase of the number of tourists that visit it, which may result in significant wildlife disturbance and/or habitat degradation by visitors [37]. Therefore, the interest in the ecological effects of roads on wildlife has increased as a result of the expansion of the transportation networks across the protected area. The main concern among conservationists and environmental planners is to know about the impact this new road will have on the guanaco population in IPP $[31,38,39]$. 
Road effects on animal population abundance can be negative, neutral or even relatively positive $[40,41]$. Therefore, based on these general revisions and on previous studies on guanacos in IPP [31,42], three contrasting predictions can be made concerning the effects of roads on this species. First, as roads have more negative effects on bigger animals, it should be expected that guanacos avoid them. Second, based on Acebes et al. [42] and Schroeder et al. [21] findings, the effect of roads on the spatial use of guanacos may be undetectable or nonexistent, being the presence of roads neutral for guanacos. Third, if guanacos perceive roads as safer sites, as found in Cappa et al. [31], they will use these spaces more frequently.

Taking all this information into account, the objectives of this study were set. The first objective is to assess the effects that the distance to roads has on the spatial use of guanacos. The second objective is to evaluate the effects of paved and unpaved roads on the spatial use of guanaco and whether there is a difference in the spatial use of these types of roads by guanacos.

\section{Materials and Methods}

\subsection{Study area}

Ischigualasto Provincial Park is located in San Juan province, Argentina (29 $55^{\prime} \mathrm{S}$; $68^{\circ} 05^{\prime} \mathrm{W}$, Figure 1). It was created in 1971 (Provincial Law $\mathrm{N}^{\circ}$ 3666), and declared World Heritage site by UNESCO (United Nations Educational, Scientific and Cultural Organization) together with Talampaya National Park in year 2000. IPP has 62,369 ha and includes a portion of Monte of Hills and Closed Basins (Monte de Sierras y Bolsones) [43]. The mean annual temperature is $22^{\circ} \mathrm{C}$, with a maximum of $45^{\circ} \mathrm{C}$ and a minimum of $-10{ }^{\circ} \mathrm{C}$. The mean precipitation is $100 \mathrm{~mm}$ per year, concentrated in summer [32].

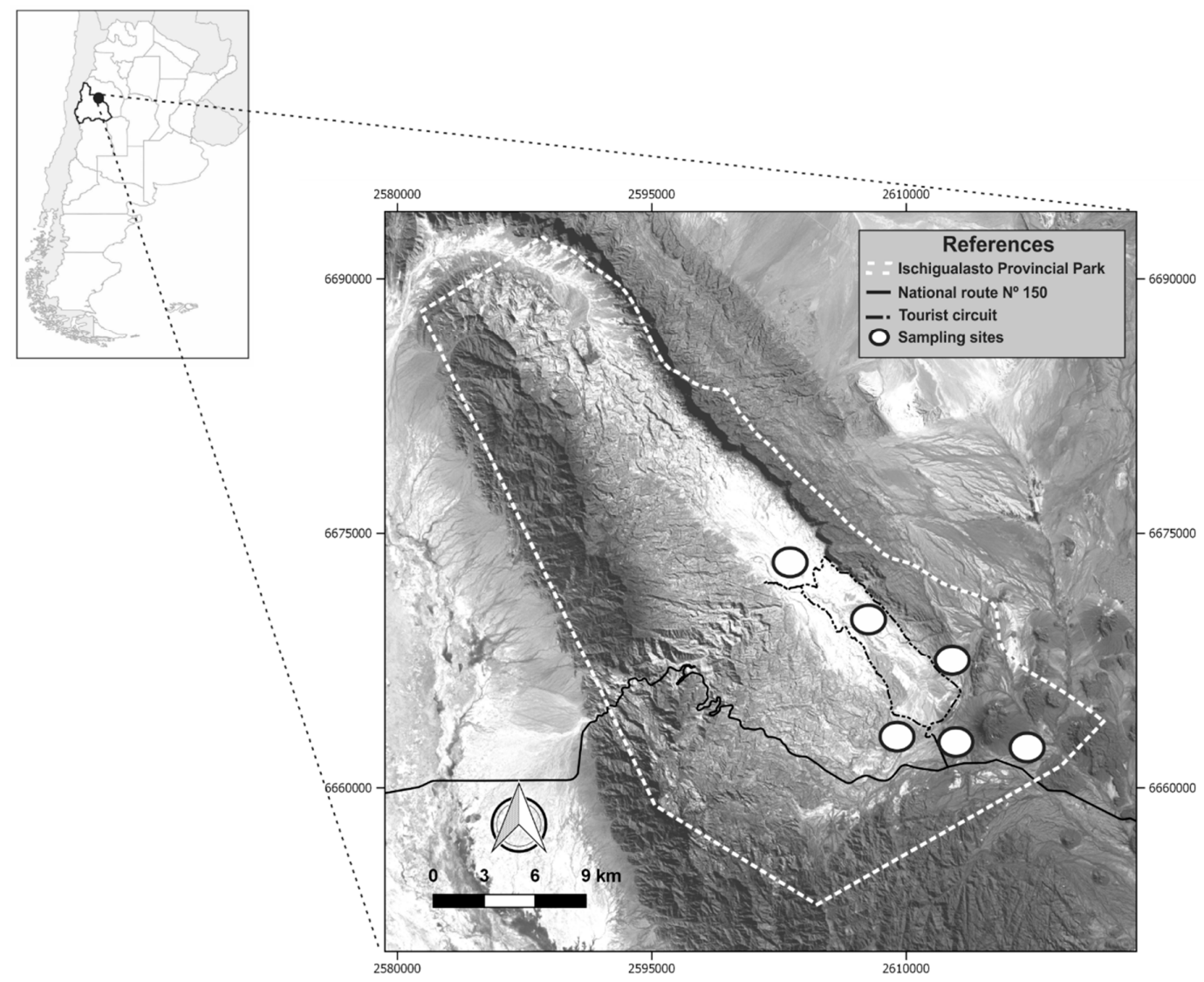

Figure 1. Geographic location of Ischigualasto Provincial Park, San Juan, Argentina and sampling sites locations. 
The typical vegetation is xerophytic, characterized mainly by open scrublands dominated by shrubs (Larrea cuneifolia, Zuccagnia punctata, Prosopis torquata), cacti (Echinopsis terschesckii), and bromeliads such as Deuterocohnia longipetala, and Tillandsia sp. It covers no more than 50 per cent of the ground $[44,45]$.

In the Park, we sampled two kinds of roads: one paved road, National route $\mathrm{N}^{\circ} 150$ (approx. $7 \mathrm{~km}$ ), and an unpaved road (tourist circuit, approx. $40 \mathrm{~km}$ ). The first has $50 \mathrm{~m}$ wide: $10 \mathrm{~m}$ paved and $40 \mathrm{~m}$ as roadside where there is a cleared area (gap zone). As regards the unpaved road, it was only $5 \mathrm{~m}$ or $7 \mathrm{~m}$ wide and it did not have a clearance zone (Figure 1). Traffic on the unpaved road was controlled between 9 a.m. and 5 p.m. with the maximum speed being $40 \mathrm{~km} / \mathrm{h}$. On the paved road there are more vehicles than on the unpaved road, reaching speeds between 80 to $120 \mathrm{~km} / \mathrm{h}$ (F. M. Cappa, personal observation).

\subsection{Data Collection}

The study was conducted over six years in the wet and dry seasons (2011-2016). We demarcated six areas: two in paved road zones and four in unpaved road zones (Figure 1). In each area, we delimited 27 transects each $5 \mathrm{~m}$ wide and $100 \mathrm{~m}$ long, located in three triads (unit sample), each separated by $300 \mathrm{~m}$ (replicate), at three different distances from both roads: $10 \mathrm{~m}, 500 \mathrm{~m}$ and $1500 \mathrm{~m}$. As proxy for guanaco spatial use intensity, we used dung heap count during four years (2011-2014). Transect clearance was carried out after each sampling, to avoid counting the same dung heap twice. In addition, one vegetation transect $(50 \mathrm{~m})$ for each strip was traced and we used the intersection line method to estimate vegetation coverage [46].

In order to yield more reliable and sound results concerning our dung heap count findings, we used camera trap sampling during three years (2014-2016) as a supplementary method. Five camera traps separated by $10 \mathrm{~m}$ (sample unit), and placed at $0.8 \mathrm{~m}$ above ground, located at three different distances from the roads: $(10 \mathrm{~m}, 500 \mathrm{~m}$ and $1500 \mathrm{~m}$ ) were set up during 15 days. Each camera was set up considering trail and signs of guanacos. We set up the camera traps to recognize motion and capture one photo after another, with a five-second delay between them. Considering the sample unit (five camera traps), all of the guanacos' photographs taken within a $<1$-hour period were disregarded so as to minimize double count, except for when individuals were differentiated by particular marks.

\subsection{Statistical Analysis}

The analyses were performed using generalized linear mixed models (GLMM). To identify collinearity between independent variables, the Spearman rank correlation was used, which is a non-parametric measure of statistical dependence. We excluded variables with a coefficient $r>|0.7|$. Then, we assessed the inflation factor (VIF) variable for any remaining collinearity on the full models and excluded variables with VIF $>5$, which indicated collinearity between predictors [47]. We corroborated the spatial correlation among sampling points using correlograms with Pearson's residuals for each model [48]. No evidence of spatial dependence was found in the models.

To analyze the guanaco spatial use intensity, models with negative binomial distribution were fitted due to greater overdispersion values when the Poisson distribution was used ( $\hat{c}>5$ ) [49]. First, we used the dung heap count as a response variable and, road (paved and unpaved road), distance from roads $(10 \mathrm{~m}, 500 \mathrm{~m}$ and $1500 \mathrm{~m})$, and their interaction, as well as, vegetation coverage and height as explicative variables. Vegetation cover and height were rescaled in order for their effects to be biologically comparable [50]. Second, we used the number of guanacos from camera trap records as a response variable. The explicative variables considered in this analysis were road and distance from roads. Season (wet and dry) nested in years, and site $(n=6)$ were used as random variables for both analyses (dung heap count and camera trap).

The site variable was the only random variable that was kept for dung heap count models since the others random variables (season and years) did not yield conclusive results for any model in both analyses $(\mathrm{P}>0.05)$. For model selection, we used the information theory method based on Akaike's information criterion corrected for small sample size (AICc). We considered Akaike weight $\left(\mathrm{w}_{\mathrm{i}}\right)$ for 
each model, which determines that the model selected is likely to be the best [51]. We also calculated the estimates with their mean errors for the best model, as well as the confidence interval $(C L=95 \%)$ for each of the estimated parameters.

We used glmmADMB package [52] to analyze the model with Negative Binomial distribution and we used nlme package [53] for Poisson distribution. We used R version 3.5.1(R Core Team 2018) in all the analyses.

\section{Results}

According to dung heap abundance, the best model explaining the intensity of guanaco's spatial use contained the following variables: road type, the distance to them and their interaction $\left(w_{i}=0.22\right.$, Table 1). We observed an increase in the spatial use of guanacos in unpaved respect to paved road ( $n=409$ and $n=141$ respectively), and this difference is bigger at large distance of both roads (Table 2, 3).

Table 1. First six models and NULL are shown and listed in decreasing order of importance according to guanaco spatial use intensity. The chosen models are in bold. $\mathrm{k}$ is the number of estimated parameters. Dist: minimum distance to the closest roads (m), cov: vegetation cover (\%), height: vegetation height $(\mathrm{cm})$, roads: paved road and unpaved road, and the interaction between distance and roads (Dist*Roads).

\begin{tabular}{ccccc}
\hline Model & $\mathbf{k}$ & AICc & $\Delta$ AICc & $w i$ \\
\hline Dist + Roads + Dist*Roads & 8 & 953.62 & 0.00 & 0.22 \\
Dist + Cov & 6 & 954.06 & 0.44 & 0.17 \\
Dist + Roads + Cov + Dist ${ }^{*}$ Roads & 9 & 954.20 & 0.59 & 0.16 \\
Dist + Roads + Height + & 9 & 955.26 & 1.65 & 0.10 \\
Dist*Roads & & & & \\
Dist + Roads + Cov + Height + & 10 & 955.56 & 1.95 & 0.08 \\
$\quad$ Dist*Roads & 7 & 955.80 & 2.18 & 0.07 \\
Dist + Roads + Cov & 3 & 963.04 & 9.42 & 0.00 \\
$\quad$ NULL & & & &
\end{tabular}

Table 2. Parameter likelihoods, estimates ( \pm standard error (SE)) and 95\% confidence interval limits (CL) for explanatory variables describing guanaco spatial use intensity: considering the minimum distance to the closest road in meters (Dist), the kind of roads (Roads) and their interaction (Dist*Roads).

\begin{tabular}{ccccc}
\hline Explanatory Variable & $\begin{array}{c}\text { Parameter } \\
\text { Likelihood }\end{array}$ & $\begin{array}{c}\text { Parameter } \\
\text { Estimate } \pm \text { SE }\end{array}$ & Lower & Upper \\
\cline { 4 - 5 } & & $0.19 \pm 0.33$ & -0.38 & 1.39 \\
Intercept & 0.99 & $0.09 \pm 0.28$ & -0.46 & 0.64 \\
Dist & & $1.19 \pm 0.30$ & 0.60 & 1.77 \\
$1500 \mathrm{~m}$ & & $0.29 \pm 0.56$ & -0.81 & 1.38 \\
$\begin{array}{c}\text { Roads } \\
\text { Dist*Roads }\end{array}$ & 0.68 & $-0.09 \pm 0.47$ & -1.02 & 0.83 \\
Paved road*500m & 0.56 & $-1.34 \pm 0.49$ & -2.30 & -0.39 \\
Paved road*1500m & & & & \\
\hline
\end{tabular}

In addition, we could record 300 guanacos in 85 independent photographs with camera traps during our sampling period of 2700 camera trap days (15 cameras x 180 days): 47 for paved road and 253 for unpaved road. The best model selected has sites as unique explicative variable $\left(\mathrm{w}_{\mathrm{i}}=0.80\right)$. These results showed that these ungulates make a less intense spatial use of paved road areas than the unpaved road $\left(\mathrm{GLMM}_{\mathrm{Binom} . \mathrm{Neg}}=\mathrm{Z}=4.19 ; \mathrm{P}=0.01\right.$, Figure 2$)$. 


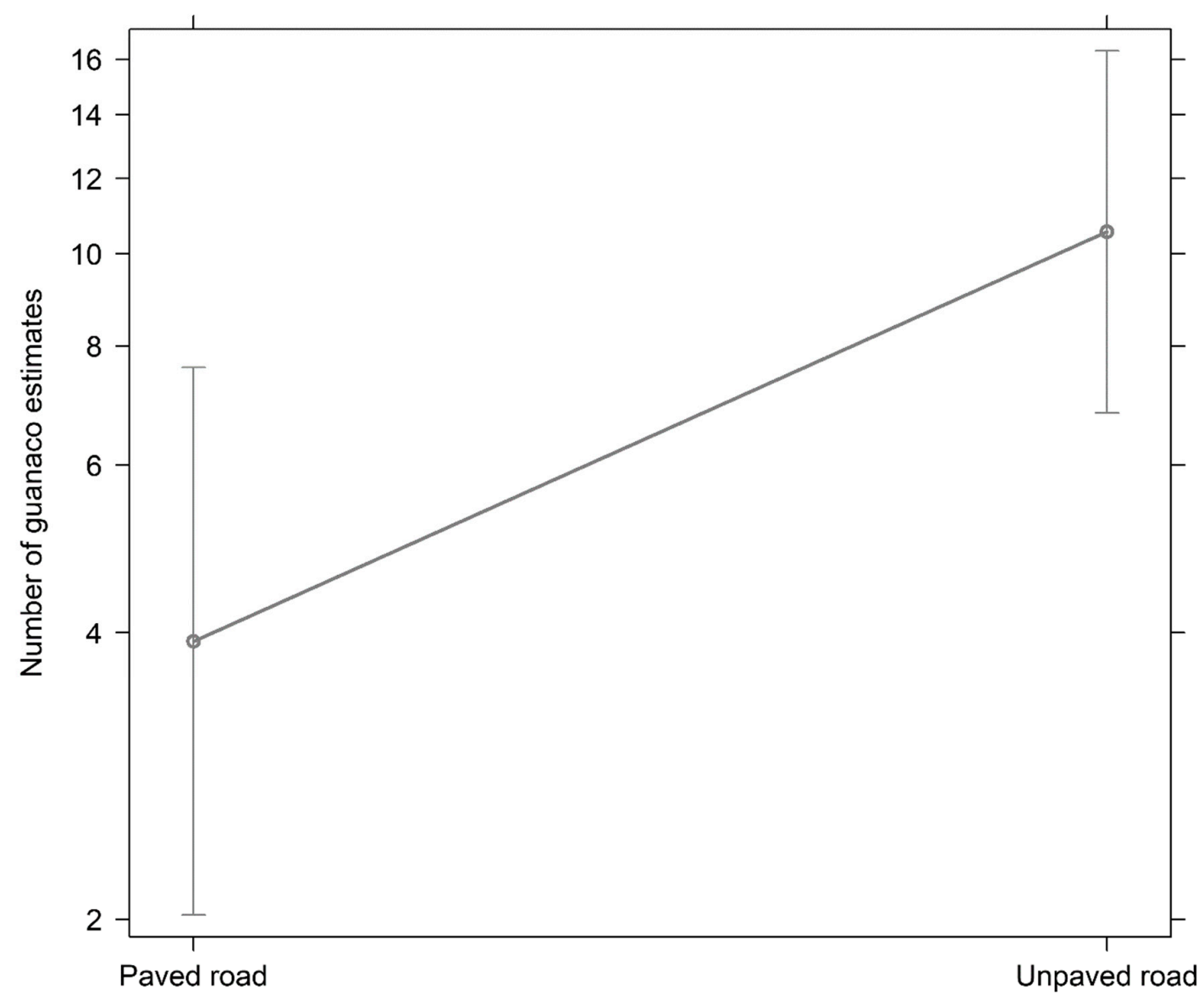

Figure 2. Mean and standard deviation of number of guanacos estimated of modelling by camera traps in relation to different kinds of roads.

\section{Discussion}

In South America, the construction of roads among other infrastructures constitutes a priority due to human development [39]. Nevertheless, construction, utilization, and management of roads have different effects on the landscape and wildlife of a place [1,54]. For instance, in Cerrado (Brazil) in the past 16 years, an estimate of $33 \%$ of forest area was lost due to roads construction [9]. As regards the impact this has on animals, road kill is one the most striking consequences of road construction and it has been widely studied $[8,18,19]$.

The numerous environmental changes generated by human activities, force animals to adjust their behavior to avoid these areas [55]. Such behavior makes it difficult for animals to access key resources and it also may limit gene flow, known as the barrier effect $[11,12,56]$. Our results show a decrease in the spatial use of paved road. This differential road use was also found in others ungulates as mule deer, wapiti [3], and caribou [10]. The low spatial use of nearby paved road areas could be making it difficult for guanacos to move inside this protected area, because this, because this road divides the park in two parts. Therefore, the effect of the paved road in the IPP could be to isolate the small population of guanacos in two even smaller populations.

In addition, we registered a decrease in dung heap count in areas close to roads, this shows that both kind of roads affect guanaco behavior but at different degrees. Our findings differ from other researchers in that no effects were found by unpaved road in guanaco's abundance [42] and spatial use [21]. Differences with our findings could be explained due to a greater vehicle traffic in IPP. Also, tourist abundance in IPP is greater than in La Payunia Provincial Reserve [21] and currently, is twice as big as it was reported in Acebes et al. [42] study for the IPP. Also, tourist affluence in IPP is greater than in La Payunia Provincial Reserve [21] and currently, is twice as big as reported in Acebes et 
al. [42] study for the IPP. Moreover, the results of our study are similar with those found in the South of Mendoza, Argentina [30], since it was found that the proximity of unpaved roads (seismic line) had negative effects on guanacos, due to the fact that there has been an increase in the use of these unpaved roads in recreational trips and poaching. The lesser use of near unpaved road areas is important, if we consider that in 2005-2006 [42] this effect was not observed in this area. This problem is probably recurrent in many protected areas that are experiencing a growth in tourism, and as other authors have highlighted, the effect of traffic volume is an important factor that influence the effect that roads have on wildlife [40,41]. Because of this, better traffic regulation policies are needed as for instance the use of vans or microbuses to minimize the impact of traffic into the tourist circuit as it was implemented in Talampaya National Park (La Rioja, Argentina).

Space use by ungulates $[3,57,58]$ and other species $[59,60]$ was assessed using the dung heap count and camera trapping registration methods. The first method is not as expensive as the second, and it provides accurate abundance index of ungulate populations [57]. Dung heap count, however, has a serious draw back; animals may use sites but not defecate on them. So, these areas may be recorded as not used by animals and as a result space use may be underestimated. To avoid this problem, we used camera trapping as a supplementary method, since they took photographs when something moved in front them. As in other research papers [58,60], we found similar results using supplementary methods: dung heap count and camera traps.

Contrary to Cappa et al. [31], our results showed that roads, especially paved roads, negatively affect the space used by guanacos. However, combining both results, it could be concluded that guanacos under use the areas near roads, even though they do not feel at risk when they use them. These results are relevant to management and conservation of this guanaco population, since the spatial segregation may lead to their isolation. Taking this into account, it is important to consider and to assess the effects that roads can have in the native fauna. Presence of these animals near to paved road without signals of fear [31], could be of great concern for guanaco conservation, because these animals are more exposed to poaching and vehicle collision. At the same time, their presence in these areas is good because these animals could be less prone to isolation. This situation poses a challenge to the managers of the area, because they should check that animals do not avoid these areas while they control poaching and animals crossing road (see [39]). On the other hand, although it was not our objective to test a particular data collection method, based on our findings and those of Schroeder et al. [21], it is important to mention that taking samples (census) of these animals from places near roads may have an impact in the results of the investigations due to the possible avoidance of these areas by guanacos. Thus, the results of this kind of research must be interpreted with caution.

Finally, it is important to highlight that we found an important road effect on the small guanaco population in a protected area (IPP) that is experiencing a growth in tourism and vehicle volume what probably generate that the found effect of roads on this species also increases. For this reason, it is essential to maintain a permanent monitoring of the effects of tourism, roads, and vehicle volume on this area, and in all protected areas in which tourism is increasing as in it.

Author Contributions: Conceptualization, F.M.C.; formal analysis, F.M.C.; investigation, F.M.C.; methodology, F.M.C.; resources, S.M.G.; writing—original draft, F.M.C.; writing—review and editing, F.M.C., C.E.B. and S.M.G.

Funding: This research was supported by 'The chica, the retamo and the algarrobo: umbrella species for the conservation of the Native Forest of the Ischigualasto Provincial Park and nearby zones. Biological interactions, effects of human activities and their mitigation', Plan for the Conservation of Native Forests Law 26.331. The Secretaría de Estado de Ciencia, Tecnología e Innovación of San Juan government support the part of the publication cost.

Acknowledgments: We thank the staff of Ischigualasto Province Park for providing all the necessary facilities during fieldwork. We also thank Gabriela Rossetti and Ana Lucia Venerdini for assisting us with the English version. We thank the reviewers for providing constructive and useful comments that improved an earlier version of this article.

Conflicts of Interest: The authors declare no conflict of interest. 


\section{References}

1. Forman, R.T.T.; Sperling, D.; Bissonette, J.; Clevenger, A.; Cutshall, C.; Dale, V.; Fahrig, L.; France, R.; Goldman, C.; Heanue, K.; et al. Road Ecology: Science and Solutions; Island Press: Washington, DC, USA, 2003.

2. Bonnot, N.; Morellet, N.; Verheyden, H.; Cargnelutti, B.; Lourtet, B.; Klein, F.; Hewison, A.J.M. Habitat use under predation risk: Hunting, roads and human dwellings influence the spatial behaviour of roe deer. Eur. J. Wildl. Res. 2013, 59, 185-193. [CrossRef]

3. Rost, G.R.; Bailey, J.A. Distribution of mule deer and elk in relation to road. J. Wildl. Manag. 1979, 43, 634-641. [CrossRef]

4. Manor, R.; Saltz, D. Effects of human disturbance on use of space and Flight distance of mountain gazelles. J. Wildl. Manag. 2005, 69, 1683-1690. [CrossRef]

5. Schroeder, N.; Ovejero, R.; Moreno, P.; Gregorio, P.; Taraborelli, P.; Mateucci, S.D.; Carmanchahi, P.D. Including species interactions in resource selection of guanacos and livestock in Northern Patagonia. J. Zool. 2013, 291, 213-225. [CrossRef]

6. Dulac, J. Global Land Transport Infrastructure Requirements. In Estimating Road and Railway Infrastructure Capacity and Costs to 2050; International Energy Agency: Paris, France, 2013.

7. Maxwell, S.L.; Fuller, R.A.; Brooks, T.M.; Watson, J.E.M. Biodiversity The ravages of guns, nets and bulldozers. Nature 2016, 536, 143-145. [CrossRef]

8. Forman, R.T.T.; Alexander, L.E. Roads and their major ecological effects. Annu. Rev. Ecol. Evol. Syst. 1998, 29, 207-231. [CrossRef]

9. Casella, J.; Paranhos Filho, A.C. The influence of highway BR262 on the loss of Cerrado vegetation cover in southwestern Brazil. Oecol. Aust. 2013, 17, 77-85. [CrossRef]

10. Dyer, S.J.; O'neill, J.P.; Wasel, S.M.; Boutin, S. Quantifying barrier effects of roads and seismic lines on movements of female woodland caribou in northeastern Alberta. Can. J. Zool. 2002, 80, 839-845. [CrossRef]

11. Jaeger, J.A.G.; Bowman, J.; Brennan, J.; Fahrig, L.; Dan Bert, D.; Bouchard, J.; Charbonneau, N.; Frank, K.; Gruber, B.; von Toschanowitz, K.T. Predicting when animal populations are at risk from roads: An interactive model of road avoidance behavior. Ecol. Modell. 2005, 185, 329-348. [CrossRef]

12. Laporte, M.; Beaudry, C.O.S.; Angers, B. Effects of road proximity on genetic diversity and reproductive success of the painted turtle (Chrysemy spicta). Conserv. Genet. 2012, 14, 21-30. [CrossRef]

13. Carr, L.W.; Fahrig, L. Effect of road traffic on two amphibian species of differing vagility. Conserv. Biol. 2001, 15, 1071-1078. [CrossRef]

14. Rytwinski, T.; Fahrig, L. Reproductive rate and body size predict road impacts on mammal abundance. Ecol. Appl. 2011, 21, 589-600. [CrossRef] [PubMed]

15. Forman, R.T.T.; Deblinger, R.D. The Ecological Road-Effect Zone of a Massachusetts (U.S.A.) Suburban Highway. Conserv. Biol. 2000, 14, 36-46. [CrossRef]

16. Forman, R.T.T. Estimate of the Area Affected Ecologically by the Road System in the United States. Conserv. Biol. 2000, 14, 31-35. [CrossRef]

17. Benítez-López, A.; Alkemade, R.; Verweij, P.A. The impacts of roads and other infrastructure on mammal and bird populations: A meta-analysis. Biol. Conserv. 2010, 143, 1307-1316. [CrossRef]

18. Groot Bruinderink, G.W.T.A.; Hazebroek, E. Ungulate traffic collisions in Europe. Conserv. Biol. 1996, 10, 1059-1067. [CrossRef]

19. Seiler, A. Trends and spatial patterns in ungulate-vehicle collisions in Sweden. Wildl. Biol. 2004, 10, 301-313. [CrossRef]

20. Taraborelli, P.; Ovejero, R.; Mosca Torres, M.E.; Schroeder, N.M.; Moreno, P.; Gregorio, P.; Marcotti, E.; Marozzi, A.; Carmanchahi, P. Different factors that modify anti-predator behaviour in guanacos (Lama guanicoe). Acta Theriol. 2014. [CrossRef]

21. Schroeder, N.M.; González, A.; Wisdom, M.; Nielson, R.; Rowland, M.M.; Novaro, A.J. Roads have no effect on guanaco habitat selection at a Patagonian site with limited poaching. Glob. Ecol. Conserv. 2018, 14, e00394. [CrossRef]

22. Franklin, W.L. Contrasting socioecologies of South America's wild camelids: The vicugna and the guanaco. Spec. Publ. J. Mammal 1983, 7, 573-629. 
23. Baldi, R.; de Lamo, D.; Failla, M.; Ferrando, P.; Funes, D.; Nugent, P.; Puig, S.; Rivera, S.; Von Thüngen, J. Plan Nacional de Manejo del Guanaco (Lama guanicoe)-República Argentina-Secretaria de Ambiente y Desarrollo Sustentable de la Nación; Anexo I: 2006. Available online: http://www.produccion-animal.com.ar/ produccion_de_camelidos/guanacos/65-plan_guanaco.pdf (accessed on 12 July 2019).

24. Marín, J.C.; Saucedo, C.E.; Corti, P.; González, B.A. Application of DNA Forensic Techniques for Identifying Poached Guanacos (Lama guanicoe) in Chilean Patagonia. J. Forensic Sci. 2009, 54, 1073-1076. [CrossRef] [PubMed]

25. Puig, S.; Videla, F.; Monge, S.; Roig, V. Seasonal variations in guanaco diet (Lama guanicoe Müller 1776) and food availability in Northern Patagonia, Argentina. J. Arid Environ. 1996, 34, 215-224. [CrossRef]

26. Reus, M.L.; Cappa, F.M.; Andino, N.; Campos, V.E.; de los Ríos, C.; Campos, C.M. Trophic interactions between the native guanaco (Lama guanicoe) and the exotic donkey (Equus asinus) in the hyper-arid Monte desert (Ischigualasto Park, Argentina). Stud. Neotrop. Fauna Environ. 2014, 49, 159-168. [CrossRef]

27. Cappa, F.M.; Borghi, C.E.; Campos, V.E.; Andino, N.; Reus, M.L.; Giannoni, S.M. Guanacos in the Desert Puna: A trade-off between drinking and the risk of being predated. J. Arid Environ. 2014, 107, 34-40. [CrossRef]

28. Marino, A.; Baldi, R. Ecological Correlates of Group-Size Variation in a Resource-Defense Ungulate, the Sedentary Guanaco. PLoS ONE 2014, 9, e89060. [CrossRef] [PubMed]

29. Vera Soto, F. Situación de Lama guanicoe en el Parque Nacional Llanos de Challe y su potencial como producto turístico. Rev. Interam. Ambient. Turism. 2014, 10, 181-188.

30. Radovani, N.I.; Funes, M.C.; Walker, R.S.; Gader, R.; Novaro, A.J. Guanaco Lama guanicoe numbers plummet in an area subject to poaching from oil-exploration trails in Patagonia. Oryx 2014, 1-9. [CrossRef]

31. Cappa, F.M.; Giannoni, S.M.; Borghi, C.E. Effects of roads on the behaviour of the largest South American artiodactyl (Lama guanicoe) in an Argentine reserve. Anim. Behav. 2017, 131, 131-136. [CrossRef]

32. Cortéz, E.; Borghi, C.E.; Giannoni, S.M. Plan de Manejo Parque Provincial Ischigualasto Fase I; Informe inédito, Ente Autárquico Ischigualasto: Gobierno de San Juan, Argentina, 2005.

33. Giannoni, S.M. Plan de Manejo del Parque Natural Provincial Ischigualasto Patrimonio Natural de la Humanidad-Provincia de San Juan, 2015.

34. Baigún, R.J.; Bolkovic, M.L.; Aved, M.B.; Li Puma, M.C.; Scandalo, R.P. Primer censo Nacional de Camélidos Silvestres al Norte del Río Colorado. In Buenos Aires: Secretaría de Ambiente y Desarrollo Sustentable de la Nación, 1st ed.; 2008; ISBN 978-987-23836-6-4. Print in Argentina.

35. Mills, L.S. Conservation of Wildlife Populations: Demography, Genetics, and Management; Blackwell Plublishing: Hoboken, NJ, USA, 2007.

36. Boo, E. Ecotourism: The Potentials and Pitfalls, Vol. 2 Country Case Studies; World Wildlife Fund: Washington, DC, USA, 1990.

37. Kerbiriou, C.; Leviol, I.; Robert, A.; Porcher, E.; Gourmelon, F.; Julliard, R. Tourism in protected areas can threaten wild populations: From individual response to population viability of the chough Pyrrhocorax pyrrhocorax. J. Appl. Ecol. 2009, 46, 657-665. [CrossRef]

38. Borghi, C.E.; Campos, C.M.; Ortuño, N.; Beninato, V.; Andino, N.; Campos, V.; de los Ríos, C.; Cappa, F.; Giannoni, S.M. Efeitos Indiretos Sobre a Fauna do Corredor Bioceánico Central em uma Área Protegida do Deserto do Monte: P. P. Ischigualasto; Bager, A., Lavras, U.F.L.A., Eds.; Ecologia de Estradas: Tendências e pesquisas, Lavras, Brazil, 2012; pp. 237-252.

39. Bager, A.; Borghi, C.E.; Secco, H. The influence of economics, politics and environment on road ecology in South America. In Handbook of Road Ecology, 1st ed.; Wiley: Hoboken, NJ, USA, 2015; Chapter 50.

40. Fahrig, L.; Rytwinski, T. Effects of roads on animal abundance: An empirical review and synthesis. Ecol. Soc. 2009, 14, 21. [CrossRef]

41. Alves Da Rosa, C.; Bager, A. Review of the factors underlying the mechanisms and effects of roads on vertebrates. Oecol. Aust. 2013, 17, 6-19. [CrossRef]

42. Acebes, P.; Traba, J.; Malo, J.E. Co-occurrence and potential for competition between wild and domestic large herbivores in a South American desert. J. Arid Environ. 2012, 77, 39-44. [CrossRef]

43. Burkart, R.; Barbaro, N.O.; Sánchez, R.O.; Gómez, D.A. Ecoregiones de la Argentina; Administración de Parques Nacionales: Buenos Aires, Argentina, 1999.

44. Márquez, J.; Martínez Carretero, E.; Dalmasso, A.; Pastrán, G.; Ortiz, S. Las áreas protegidas de la provincia de San Juan (Argentina) II. La vegetación del Parque Provincial de Ischigualasto. Multequina 2005, 14, 1-27. 
45. Acebes, P.; Ovejero, R.; Traba, J.; Malo, J.E.; Borghi, C.E. Density and habitat use at different spatial scales of a guanaco population (Lama guanicoe) in the Monte desert of Argentina. Mammalia 2010, 74, 57-62. [CrossRef]

46. Maestre, F.T.; Escudero, A. Is the patch size distribution of vegetation a suitable indicator of desertification processes? Ecology 2009, 90, 1729-1735. [CrossRef] [PubMed]

47. Heiberger, R.M.; Holland, B. Statistical Analysis and Data Display: An Intermediate Course with Examples in S-Plus, R, and SAS; Springer: New York, NY, USA, 2004.

48. Zuur, A.; Leno, E.N.; Walker, N.; Saveliev, A.A.; Smith, G.M. Mixed Effects Models and Extensions in Ecology with R; Springer: New York, NY, USA, 2009.

49. Crawley, M.J. The $R$ Book, 1st ed.; John Wiley and Sons Ltd.: Hoboken, NJ, USA, 2007; ISBN 13: 978-0-470-51024-7.

50. Schielzeth, H. Simple means to improve the interpretability of regression coefficients: Interpretation of regression coefficients. Methods Ecol. Evol. 2010, 1, 103-113. [CrossRef]

51. Burnham, K.P.; Anderson, D.R. Model selection and multimodel inference. In A Practical Information-Theoretic Approach; Springer: New York, NY, USA, 2002.

52. Fournier, D.A.; Skaug, H.J.; Ancheta, J.; Ianelli, J.; Magnusson, A.; Maunder, M.; Nielsen, A.; Sibert, J. AD Model Builder: Using automatic differentiation for statistical inference of highly parameterized complex nonlinear models. Optim. Methods Softw. 2012, 27, 233-249. [CrossRef]

53. Pinheiro, J.; Bates, D.; Debroy, S.; Sarkar, D.; EISPACK; Heisterkamp, S.; Van Willigen, B.; R-core Team. nlme: Linear and Nonlinear Mixed Effects Models. R Package Version 2014, 3, 117.

54. Karlson, M.; Mörtberg, U.; Balfors, B. Road ecology in environmental impact assessment. Environ. Impact Assess. Rev. 2014, 48, 10-19. [CrossRef]

55. Coffin, A.W. From roadkill to road ecology: A review of the ecological effects of roads. J. Transp. Geogr. 2007, 15, 396-406. [CrossRef]

56. Leblond, M.; Dussault, J.C.; Ouellet, P. Avoidance of roads by large herbivores and its relation to disturbance intensity. J. Zool. 2012, 289, 32-40. [CrossRef]

57. Cromsigt, J.P.G.M.; Prins, H.H.T.; Olff, H. Habitat heterogeneity as a driver of ungulate diversity and distribution patterns: Interaction of body mass and digestive strategy. Divers. Distrib. 2009, 15, 513-522. [CrossRef]

58. Li, X.; Buzzard, P.; Jiang, X. Habitat associations of four ungulates in mountain forests of southwest China, based on camera trapping and dung counts data. Res. Popul. Ecol. 2014, 56, 251-256. [CrossRef]

59. Landsberg, J.; Stol, J. Spatial distribution of sheep, feral goats and kangaroos in woody rangeland paddocks. Rangel. J. 1996, 18, 270-291. [CrossRef]

60. Garrote, G.; Pérez de Ayala, R.; Tellería, J.L. A comparison of scat counts and camera-trapping as means of assessing Iberian lynx abundance. Eur. J. Wildl. Res. 2014. [CrossRef] 